\title{
PENGARUH STRES INTERNAL DAN STRES EKSTERNAL PADA COPING DIADIK NEGATIF
}

\author{
Yonathan Aditya Goei \\ Fakultas Psikologi \\ Universitas Pelita Harapan \\ UPH Tower Lippo Karawaci \\ Jalan MH Thamrin, Boulevard 1100 \\ Tangerang 15811 \\ yonathan.aditya@uph.edu
}

\begin{abstract}
A lot of research found the negative effect of stress on the ability of couples to cope. This present study tried to further study this phenomenon by differentiating the source of stress and using dyadic analysis. This study tested the effect of external and internal stress on negative dyadic coping. The data was collected from 203 couples, and Actor-Partner Interdependence Model (APIM) was used to guide the statistical analysis. The results showed external stress did not have direct effect on negative dyadic coping. However, external stress had a direct effect on internal stress. Internal stress had a direct effect on negative dyadic coping. It was also found that internal stress has a couple oriented pattern, internal stress affected the negative dyadic coping of actor and partner as well. Implication of these finding was discussed.
\end{abstract}

Keyword: external stress, internal stress, negative dyadic coping, APIM

\begin{abstract}
Abstrak
Banyak penelitian menemukan pengaruh buruk stres terhadap kemampuan pasangan melakukan coping. Penelitian ini mencoba lebih lanjut meneliti fenomena tersebut dengan membedakan sumber stres dan menggunakan analisa diadik. Penelitian ini menguji pengaruh stres internal dan stres eksternal terhadap coping diadik negatif pasangan. Data dikumpulkan dari 203 pasangan, dan metode statistik dilakukan mengikuti Actor-Partner Interdependence Model (APIM). Hasil penelitian menunjukkan bahwa stres eksternal tidak mempunyai pengaruh langsung terhadap coping diadik negatif, tapi stres eksternal akan mempengaruhi stres internal yang kemudian akan mempengaruhi coping diadik negatif. Stress internal mempunyai orientasi pasangan, oleh karena itu stress internal suami bukan hanya mempengaruhi coping suami tapi juga istri. Implikasi dari hasil ini juga didiskusikan.
\end{abstract}

Kata kunci: stres eksternal, stres internal, coping diadik negatif, APIM. 


\section{PENDAHULUAN}

Pernikahan merupakan lembaga penting dalam kehidupan manusia. Lembaga ini mempunyai berbagai fungsi seperti mengatur kekerabatan, membentuk identitas keluarga, mengatur tingkah laku seksual, mendukung pendidikan anak, saluran pengaliran ekonomi dan pengasuhan antar generasi, serta menempatkan seseorang dalam keluarga, kekerabatan, dan masyarakat (Whitehead, 2004). Akan tetapi, fakta di lapangan menunjukkan kestabilan dan kualitas pernikahan menurun, seperti yang ditunjukkan dari meningkatnya angka perceraian dan menurunnya kualitas pernikahan (Rogers \& Amato, 1997). Badan Urusan Peradilan Agama Mahkamah Agung Republik Indonesia mencatat terjadinya kenaikan angka perceraian 70\% antara tahun 2005 dan tahun 2010 (Putra, E.P., 2012).

Perceraian ini juga tidak mengenal agama. Kelompok born again christian di Amerika Serikat yang berjanji hanya kematian yang bisa memisahkan mereka, juga mempunyai angka perceraian yang sama dengan kelompok lain di Amerika Serikat (Barna, 2004). Tingginya angka perceraian dan turunnya kepuasan pernikahan ini mempunyai pengaruh buruk bagi kesehatan mental dan fisik bagi bagi pasangan maupun anak-anak mereka. Fincham (2003) menyimpulkan bahwa pernikahan yang tidak berbahagia berhubungan dengan penyakit seperti kanker, sakit jantung, penyakit kronis. Pernikahan yang tidak berbahagia juga akan menimbulkan konflik pasangan yang akhirnya berakibat buruk bagi perkembangan anak.

Seriusnya akibat yang ditimbulkan dari pernikahan yang buruk ini menyebabkan banyak ahli tertarik untuk meneliti masalah pernikahan. Kebanyakan penelitian terdahulu menekankan pada masalah komunikasi dan konflik (Bradbury, Rogge \& Lawrence, 2001). Mereka berpendapat problem dalam pernikahan disebabkan oleh kurangnya kemampuan komunikasi, akan tetapi beberapa peneliti mulai menyadari kemampuan komunikasi yang baik tidak menjamin kepuasan pernikahan. Oleh karena itu fokus penelitian pada pernikahan mulai bergeser ke arah yang lain. Rauer, Karney, Garvan dan Hou (2008) mengusulkan perlunya meneliti tentang stress dan bagaimana pasangan mengatasi stres.

Penelitian tentang stres dalam pernikahan juga banyak berfokus pada stres mayor. Memperhatikan hal-hal di atas penelitian ini berfokus pada pengaruh stres sehari-hari khususnya stres dari luar hubungan pernikahan dan stres dari hubungan pernikahan pada kemampuan coping diadik dari pasangan. Coping diadik adalah proses coping yang melibatkan kedua pihak dari pasangan. Berbagai penelitian menunjukkan bahwa coping diadik menyumbangkan $35 \%$ variance dari kepuasan pernikahan. Oleh karena itu akan bermanfaat jika pasangan bisa mengetahui ha-hal yang mempengaruhi coping diadik, sehingga mereka bisa mencegah terjadinya coping diadik yang buruk. Dengan demikian mereka bisa mencegah pernikhaan mereka memburuk. Penelitian ini juga menggunakan metode statistik yang relatif baru yang disebut APIM (Actor-Partner Interdependence Model). APIM memungkinkan peneliti untuk meneliti keterkaitan antara suami istri, misalnya pengaruh stres istri terhadap kemampuan coping istri dan juga suami. Pasangan suami istri saling mempengaruhi satu sama lain, oleh karena itu menganalisa keterkaitan antara suami istri dengan menggunakan analisa regresi berganda akan melanggar asumsi observsi bebas dari statistik (Kenny, Kashy \& Cook, 2006).

\section{Stres dalam pernikahan}

Pasangan dalam sebuah hubungan pernikahan saling mempengaruhi satu sama lain. Tindakan atau keadaan suami akan mempengaruhi istri dan sebaliknya (Cutrona \& Gardner, 2006). Demikian pula halnya dengan stres. Stres dari suami/istri akan mempengaruhi istri/suami. Oleh karena itu Bodenmann (1995) berpendapat stres dalam pernikahan sebaiknya dikonseptualisasikan sebagai stres 
diadik. Stres diadik didefinisikan sebagai keadaan stres yang menimpa atau mempengaruhi pasangan (Bodenmann, 1995).

Mayoritas penelitian tentang pengaruh stres pada pernikahan tidak membedakan sumber stres. Hal inilah yang mungkin merupakan salah satu penyebab penelitian tentang pengaruh stres pada pernikahan mendapat hasil yang berbeda-beda bahkan bertentangan. Oleh karena itu Randall dan Bodenmann (2009) mengusulkan perlunya membagi stres dalam pernikahan menurut sumbernya. Mereka menamakan stres yang berasal dari luar hubungan pernikahan seperti stres karena tetangga, pekerjaan, atau anak-anak sebagai stres eksternal. Pada lain pihak, stres yang berasal dari masalah dalam pasangan itu sendiri dinamakan sebagai stre internal. Contoh dari stres internal antara lain stres yang disebabkan karena perbedaan kebiasaan, atau tujuan hidup diantara pasangan suami-istri.

Stres internal dan stres eksternal mempunyai pengaruh berbeda pada hubungan suami istri. Stres eksternal tidak selalu berakibat buruk, bahkan kadang-kadang stres eksternal ini dapat meningkatkan kepuasan pernikahan. Akan tetapi stres ini dapat mempengaruhi stres internal sehingga berpengaruh buruk, jika tidak ditangani dengan baik. Di lain pihak, stres internal mempunyai pengaruh yang lebih serius pada kehidupan pernikahan daripada stres eksternal (Story \& Bradbury, 2004).

\section{Coping Diadik}

Sama seperti stres dalam pernikahan, coping dalam hubungan suami-istri juga sebaiknya dikonseptualisaikan sebagai coping diadik, karena coping dari salah satu pasangan akan mempengaruhi pasangan yang lain. Bodenmann (2005, hal.36) menyatakan, "One cannot examine one partner's stres appraisals or coping efforts without considering the effects on the other partner and the marriage"

Bodenmann (1995) yang pertama kali memperkenalkan istilah coping diadik ini mendasarkan teorinya dari teori Lazarus dan Folkman (1984), dan memperluasnya sehingga mencakup interaksi antara suami dan istri. Bodenmann mendefinisikan coping diadik sebagai suatu proses dimana pasangan berkolaborasi dan berbagi sumber daya untuk mengatasi permasalahan yang mempengaruhi pasangan baik langsung ataupun tidak langsung.

Dengan demikian coping diadik selalu memperhitungkan keterkaitan antara suami dan istri. Sumber stres memang tidak selalu harus berasal dari kedua pasangan (suami dan istri) secara bersamaan. Bisa saja stres berasal dari salah satu pasangan, tapi akhirnya stres dari salah satu pasangan itu akan mempengaruhi pasangan yang lain, sehingga menuntut coping dari kedua belah pihak.

Salah satu jenis dari coping diadik ini adalah coping diadik negatif (Bodenmann, 2005). Coping diadik negatif pada intinya adalah tindakan pertolongan yang dilakukan oleh salah satu pasangan kepada pasangan yang lain, akan tetapi tidak dilakukan dengan tulus dan benar. Misalnya, tindakan pertolongan yang disertai dengan cemoohan, tindakan/kata-kata kasar, dilakukan dengan setengah hati, atau pura-pura menolong padahal tidak melakukan apa yang dijanjikan.

Model stres transaksional dari Lazarus dan Folkman (1984) mengindikasikan bahwa strategi coping yang dipakai seseorang dapat berubah tergantung dari keadaan stres yang dihadapi. Coping bukan merupakan sesuatu yang statis, tapi dinamis tergantung dari jenis stresor dan apraisal seseorang pada waktu tertentu. Dengan demikian strategi coping seseorang dapat berubah jika jenis stresor yang dihadapi dan/atau appraisal seseorang terhadap stresor tersebut berubah (Moos \& Holahan, 2003).

Bodenmann sebagai pencetus coping diadik juga mempunyai konsep yang serupa tentang adanya pengaruh jenis stres dan appraisal pada tipe coping diadik yang akan dipakai oleh pasangan. Dalam konteks pernikahan jenis stres dan khususnya asal stres berpengaruh terhadap tipe coping diadik yang dipakai. Pasangan akan lebih mudah bekerja sama jika sumber permasalahan berasal dari luar hubungan mereka berdua seperti masalah pekerjaan atau anak, dibandingkan dengan jika sumber 
permasalah berasal dari hubungan mereka berdua seperti perbedaan hobi atau tujuan hidup. Misalnya seorang suami/istri akan lebih mudah menolong pasangannya yang sedang mengalami masalah di kantor, daripada menolong pasangannya yang baru saja bertengkar dengan mereka karena perbedaan tempat tujuan wisata. Dengan demikian dibandingkan dengan stres eksternal, stres internal akan lebih berpengaruh terhadap coping diadik negatif (Randall \& Bodenmann, 2009).

\section{Tujuan Penelitian}

Tujuan dari penelitian ini adalah untuk mengetahui keterkaitan antara stres eksternal, stres internal, dan coping diadik negatif. Analisa data dilakukan dengan mengikuti Actor-Partner Interdependence model (APIM) (lihat diagram 1). Model ini memungkinkan peneliti untuk mengetahui baik efek aktor maupun efek partner. Yang dimaksud dengan efek aktor adalah pengaruh variabel bebas individu terhadap variabel terikat individu itu sendiri, sedangkan efek partner adalah pengaruh variabel bebas individu terhadap variabel terikat pasangannya. Dengan demikian model APIM ini dapat menangkap efek keterkaitan antara suami dan istri sehingga diharapkan dapat memberikan gambaran yang lebih akurat tentang relasi pernikahan dibandingkan dengan perhitungan statistik biasa regresi berganda (Charania \& Ickes, 2009). Regresi berganda tidak dapat mengukur efek variabel bebas individu terhadap variabel terikat psangannya karena akan melanggar asumsi pengamatan independen dari statistik (Kenny, Kashy \& Cook, 2006).

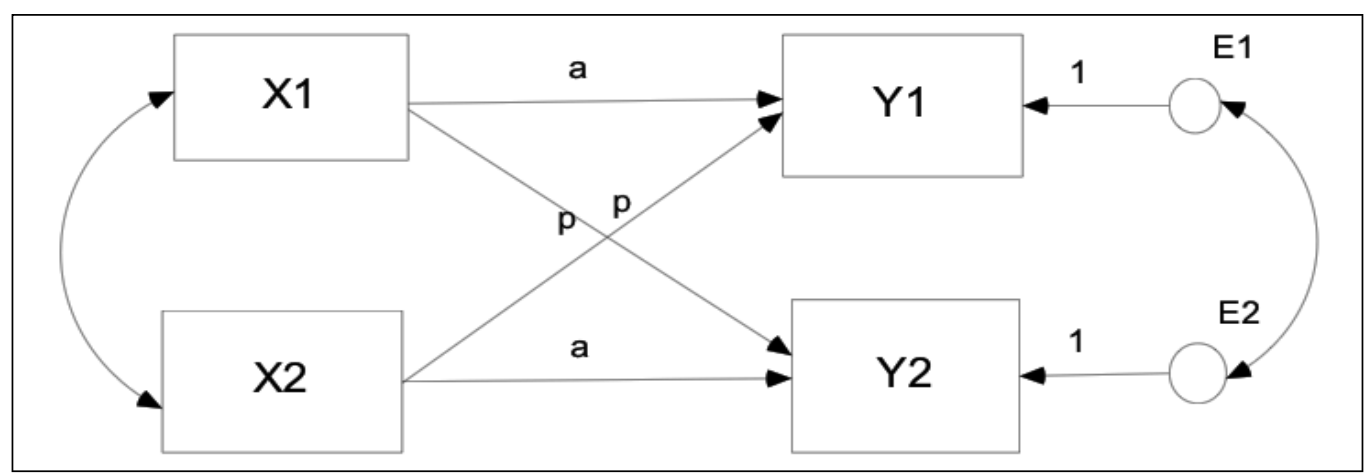

Gambar 1. Model APIM. Ada dua anggota dalam dyad (1 dan 2), satu variabel bebas (X) dan satu variabel tergantung (Y). E menggambarkan error variance yang tidak dijelaskan oleh APIM. a adalah efek aktor sdangkan p efek partner.

Analisa diagram kerja diilustrasikan di gambar 2.

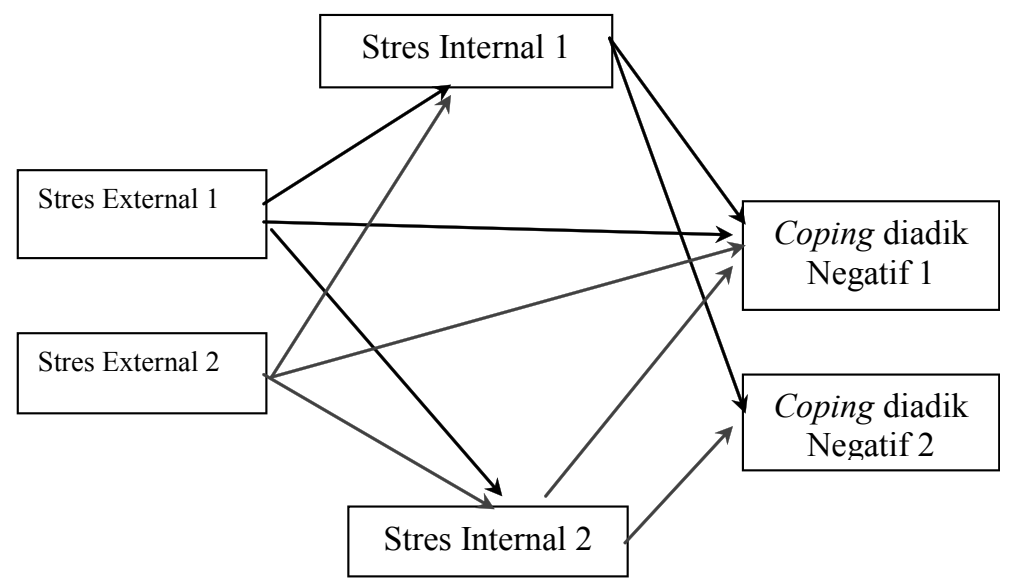

Gambar 2. Hubungan antara stres eksternal-stres internal- coping diadik negatif. Kode: 1= pria, $2=$ wanita. 


\section{Pertanyaan riset}

Bagaimana stres eksternal dan stres internal seseorang mempengaruhi coping diadik negatif baik pada diri sendiri maupun pasangannya?

\section{Hipotesa}

1. Stres eksternal mempunyai pengaruh signifikan terhadap stress internal dan coping negatif baik terhadap diri sendiri maupun pasangan.

2. Stres internal mempunyai pengaruh signifikan terhadap coping negatif baik terhadap diri sendiri maupun pasangan

\section{METODE}

\section{Partisipan}

Partisipan dari penelitian ini adalah jemaat dari berbagai gereja di Jakarta, Bandung, Yogyakarta, dan Surabaya. Mereka adalah pasangan yang sudah menikah paling sedikit satu tahun dan baik suami dan istri bersedia mengisi kuesioner tanpa saling berkonsultasi.

Beerdasarkan rekomendasi yang diberikan oleh Ackerman, Donnellan and Kashy (2011), untuk model penelitian ini dibutuhkan jumlah sampel paling sedikit 180 pasangan. Jumlah kuesioner yang disebarkan adalah 350 pasangan, 230 pasangan mengembalikan kuesioner, tetapi data dari 27 pasangan tidak dapat dipakai karena beberapa alasan seperti, hanya satu pihak dari pasangan yang mengisi, atau lupa mengisi data demografi. Dengan demikian ada data dari 203 pasangan yang dapat dianalisa.

Usia responden berkisar antara 20 dan 60 tahun dengan rata-rata 41.7 tahun $(S D=7.9)$. Lama pernikahan antara 1 sampai 39 tahun dengan rata-rata 13.9 tahun $(S D=7.9)$. Mayoritas pasangan mempunyai dua anak. Latar belakang etnis dari para responden adalah: $57.6 \%$ keturunan Tionghoa, $20.4 \%$ Jawa, $13.8 \%$ Batak, dan $8.2 \%$ yang lain adalah Minahasa, Timor, Maluku adan etnis campuran. Lebih dari $59 \%$ responden lulus sarjana dan lebih dari 11\% mempunyai gelar pasca sarjana. Dari 406 responden $31 \%$ diantaranya mempunyai pengeluaran keluarga diatas Rp. 10.000.000, $26 \%$ antara Rp. 6.000 .000 - Rp. 10.000 .000 dan 26\% antara Rp. 3.000 .000 - Rp. 6.000.000. Dalam penelitian ini tidak ada satupun dari variabel demografi ini mempunyai hubungan signifikan dengan kepuasan pernikahan.

\section{Alat ukur}

Pertanyaan Demografi. Responden diminta untuk mengisi umur, jenis kelamin, etnis, lama menikah, pengeluaran keluarga, jumalh anak, dan pendidikan tertinggi.

Dyadic Coping Inventory. Dyadic Coping Inventory digunakan untuk mengukur strategi coping diadik dari responden. DCI adalah alat ukur yang terdiri dari 37 item dengan 5 pilihan likert. Inventori ini mengukur persepsi seseorang tentang coping diadik dari diri sendiri dan pasangannya. Alat ukur ini mempunyai 9 dimensi, yaitu komunikasi stress dari diri sendiri, coping diadik mendukung diri sendiri, coping diadik delegasi diri sendiri, coping diadik negatif diri sendiri, komunikasi stress pasangan, coping diadik mendukung pasangan, coping diadik delegasi psangan, coping diadik negatif pasangan, coping diadik bersama, tapi hanya dimensi coping diadik negatif yang dipakai.

Instrumen ini mempunyai konsistensi internal yang bagus (.77) dan telah melalui test analisa faktor (Bodenmann, 2008). Dalam penelitian ini didapatkan level alpha yang cukup bagus (pria = 
.77 , wanita $=.76$ ). Contoh pertanyaan seperti, pasangan saya menyediakan dukungan tetapi dengan terpaksa dan tanpa motivasi.

Multidimensionnal Stres Questionnaire for Couples (MSF-P). MSF-P dipakai untuk mengukur level stres yang dipersepsikan. Alat ukur ini dikembangkan oleh Bodenmann (2007) untuk menganalisa hubungan antara berbagai jenis stres yang dipersepsikan dengan coping diadik pada hubungan pernikahan. MSF-P mempunyai 6 skala, tetapi dalam peneltian ini hanya satu skala yang dipakai (internal and external). Confirmatory Factor Analysis (CFA) telah dilakukan dengan menggunakan AMOS pada dua skala dari MSF-P dan didapatkan struktur dua faktor terbukti mempunyai "adequate fit" $($ RMSEA $=.074$ and RMR $=.034)$. Dalam enelitian ini didapatkan alpha level yang cukup baik untuk internal perceived stres (pria $=.77$, wanita $=.76$ ) dan eksternal perceived stres (pria $=.76$, wanita $=.75$ ). Alat ukur ini meminta responden untuk menyatakan pendapat tentang seberapa menekan situasi yang ditanyakan dalam alat ukur. Contoh pertanyaan seperti, perbedaan pendapat dengan pasangan, masalah kesehatan.

\section{Prosedur}

Penerjemahan alat ukur. Semua alat ukur ditulis dalam bahasa Inggris, oleh karena itu perlu diterjemahkan ke bahasa Indonesia karena mayoritas responden tidak mengerti bahasa Inggris dengan baik. Penerjemahan dilakukan sesuai dengan metode "back translation" (Behling \& Law, 2000). Semua alat ukur diterjemahkan kedalam bahasa Indonesia, kemudian alat ukur dalam bahasa Indonesia ini diterjemahkan kembali ke dalam bahasa Inggris oleh penterjemah yang tidak mengetahui alat ukur asli (dalam bahasa Inggris). Alat ukur hasil penterjemahan kembali ke bahasa Inggris ini dibandingkan kembali dengan alat ukur asli, ternyata tidak ada perbedaan yang signifikan. Setelah itu alat ukur yang sudah dalam bahasa Indonesia itu diperiksa kecocokannya dengan budaya Indonesia. Kata-kata atau ungkapan yang tidak umum dipakai di Indonesia diganti dengan kata-kata dan ungkapan yang lebih sesuai. Misalnya dalam MSF-P ditanyakan mengenai ukuran apartemen, hampir semua responden tinggal di rumah oleh karena itu apartemen diganti dengan rumah.

Prosedur pengumpulan data. Dalam pengumpulan data peniliti menemui responden secara langsung ataupun menemui individu kunci yang akan membantu dalam pengumpulan data. Semua responden baik yang bertemu dengan peneliti langsung ataupun bertemu dengan individu kunci mendapatkan informed consent dan satu set alat ukur. Setelah mereka mengisi kuesioner mereka mendapatkan debriefing information.

\section{Teknik Analisis}

Langka pertama dalam analisa data adalah filter data untuk memeriksa akurasi pemasukan data, data yang hilang, dan asumsi analisa multivariate analysis. Analisa data dilakukan dengan menggunakan Actor-Partner Interdependence Model (APIM) dan parameter APIM dihitung dengan menggunakan multi level modelling. Multi level modelling adalah metode statistik yang dipakai untuk menganalisa data yang mempunyai lebih dari satu tingkat. Dalam penelitian ini ada dua tingkat. Tingkat pertama adalah dyad dan tingkat kedua adalah suami dan istri (Kenny, Kashy \& Cook, 2006).

Sebelum analisa APIM dilakukan, perlu dilakukan Omnibus Test of Distinguishability untuk mengetahui apakah data dari masing-masing pihak dalam dyad (suami dan istri) berbeda secara empiris. Pasangan dalam penelitian ini secara konsep dapat dibedahkan karena mereka adalah pria dan wanita, akan tetapi belum tentu dapat dibedahkan secara empiris (Kenny \& Kashy, 2006). Hasil. tes menunjukkan data pasangan dari penelitian ini berbeda secara empiris. Oleh karena itu analisa data yang dipakai adalah APIM untuk distinguishable dyad yaitu APIM untuk pasangan yang berbeda secara empiris. 


\section{HASIL \& ANALISA}

\section{Analisa Deskriptif dan Pendahuluan}

Analisa deskriptif dan pendahuluan mencakup rata-rata dan standar deviasi untuk semua variabel bebas dan variabel terikat baik untuk pria maupun wanita, dan paired samples $t$ tests untuk memeriksa perbedaan nilai pria dan wanita di tiap variabel. Selain itu korelasi antara semua variabel bebas dan terikat untuk pria dan wanita ditampilkan dalam matrik korelasi.

Tabel 1 mengpresentasikan nilai rata-rata dan standar deviasi untuk semua variabel yang diteliti. Tidak anda perbedaan signifikan antara pria dan wanita dalam semua variabel.

Tabel 1.Nilai rata-rata dan standar deviasi untuk pria dan wanita

\begin{tabular}{|l|c|c|c|c|c|c|}
\hline & \multicolumn{2}{|c|}{ Pria } & \multicolumn{2}{c|}{ Wanita } & & \\
\hline Variabel & $M$ & $S D$ & $M$ & $S D$ & $T$ & $p$ \\
\hline Stres Internal & 1.82 & .53 & 1.88 & .55 & -1.65 & .10 \\
\hline Stres Eksternal & 1.83 & .53 & 1.82 & .53 & .30 & .77 \\
\hline Coping diadik Negatif & 1.00 & .6 & 1.03 & .58 & -.95 & .34 \\
\hline
\end{tabular}

${ }^{*} p<.05$

Sementara korelasi antara semua variabel baik untuk pria maupun wanita ditunjukkan dalam Tabel2. Angka di bidang diagonal tabel menunjukkan korelasi antara pria dan wanita untuk semua variabel yang diteliti. Nilai dari pasangan suami istri untuk stres internal $(r=.53, p<.01)$, stres eksternal $(r=.26, p<.01)$, dan coping diadik negatif $(r=.58, p<001)$ mempunyai korelasi signifikan. Hasil ini mendukung dugaan bahwa pasangan suami istri saling mempengaruhi satu sama lain. Hal ini yang menyebabkan analisa untuk pasangan suami istri tidak dapat dilakukan dengan menggunakan metode statistik biasa (multiple regression) karena asumsi observasi independen tidak dapat dipenuhi, oleh karena itu penelitian ini menggunakan analisa diadik dan khususnya Actor-Partner Interdependence Analysis (APIM).

Tabel 2. Korelasi untuk semua variabel (pria dan wanita)

\begin{tabular}{|l|c|c|c|}
\hline & \multicolumn{2}{|c|}{ Pria } & \\
\hline Wanita & Internal Stres & External Stres & Coping Diadik Negatif \\
\hline Stres Internal & $\mathbf{. 5 3}^{*}$ & $\mathbf{. 5 6 *}$ & $\mathbf{. 2 5 ^ { * }}$ \\
\hline Stres Eksternal & $\mathbf{. 4 3}^{*}$ & $\mathbf{. 2 6}^{*}$ & .14 \\
\hline Coping Diadik Negatif & $\mathbf{. 2 5}^{*}$ & $\mathbf{. 1 5}^{*}$ & $\mathbf{. 5 8 *}$ \\
\hline
\end{tabular}

Note. Korelasi untuk pria berada di atas diagonal, korelasi untuk wanita ada di bawah diagonal.

Nilai diagonal menggambarkan korelasi antara variabel pria dan wanita. $* \mathrm{p}<.05$

Tabel 2 juga menunjukkan bahwa stres eksternal mempunyai korelasi signifikan dengan stres internal akan tetapi tidak mempunyai korelasi signifikan dengan coping diadik negatif, hal ini berlaku baik untuk pria maupun wanita. Untuk pria dan wanita, coping diadik negatif hanya mempunyai korelasi signifikan dengan stres internal. 
Analisis Diadik:

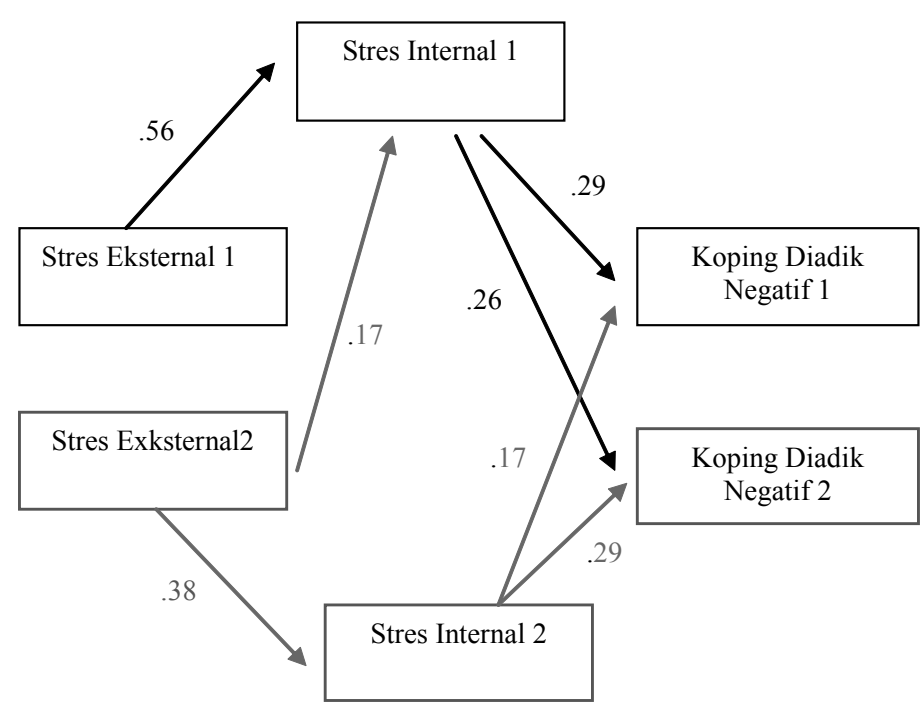

Gambar 3. APIM, Kode: 1= pria. $2=$ wanita.

\section{DISKUSI}

Nilai signifikan dari analisa APIM ditampilkan di grafik 3 di atas. Hasil ini menunjukkan bahwa coping diadik negatif tidak dipengaruhi oleh stres eksternal tapi hanya dipengaruhi oleh stress internal, akan tetapi stres internal dipengaruhi oleh stres eksternal. Hal ini mengindiksikan bahwa stres dari luar hubungan suami istri, seperti stress karena pekerjaan, konflik dengan tetangga, dan lain-lain tidak mempunyai pengaruh langsung terhadap coping negatif pasutri. Walaupun demikian, stres eksternal akan memperburuk stres internal yaitu stres dari permasalahan diantara pasangan suami istri seperti perbedaan kepribadian atau tujuan hidup. Dengan kata lain, jika pasangan suami istri itu mempunyai masalah internal, stres eksternal akan memperburuk permasalahan mereka yang akhirnya membuat coping negatif juga semakin parah.

Pengaruh stres eksternal terhadap stres internal pada pria lebih tinggi daripada pengaruh yang sama pada wanita. Pria yang mempunyai stres dari luar relasi seperti permasalah di tempat kerja, akan cenderung untuk membawa stres ini ke dalam relasi suami istri, sedangkan wanita lebih bisa mengurangi pengaruh itu. Hal ini mengindikasikan bahwa wanita lebih bisa mengelola stres lebih baik daripada wanita, mengingat tingkat stres eksternal pria dan wanita tidak berbeda (lihat tabel 1). Hasil ini sesuai dengan penelitian Repetti dan Wood (1997). Mereka menemukan bahwa wanita mampu mengelola stres lebih baik dibandingkan dengan pria, sehingga wanita lebih bisa mencegah agar stres eksternal tidak terbawa kedalam relasi dengan pasangan mereka. Ketidak mampuan pria Indonesia untuk mengelola emosi dibandingkan dengan wanita, kemungkinan disebabkan oleh pendidikan. Pria Indonesia dibiasakan untuk tidak menunjukkan emosi. Dari kecil mereka dididik untuk tidak menangis atau menunjukkan emosi yang berlebihan di depan umum, karena hal tersebut dianggap sebagai tanda kelemahan. Akibatnya mereka tidak mengenal emosi mereka, yang juga berarti sulit bagi mereka untuk mengelola emosi mereka.

Berbeda dengan hasil korelasi, hasil analisa diadik ini dapat menunjukkan interaksi antara suami dan istri, sesuatu yang tidak dapat ditunjukkan oleh analisa korelasi. Coping diadik negatif dari pria dan wanita dipengaruhi oleh level internal stres dari dirinya sendiri (efek aktor) dan juga pasangannya (efek partner). Stres mengurangi kemampuan seseorang untuk mengelola kejadian yang menimpa 
dirinya dengan baik, sehingga mereka cenderung untuk tidak dapat mengelola stres dengan baik dan tidak melakukan coping dengan baik (Neff \& Karney, 2004). Dengan demikian semakin besar level stres internal seseorang, semakin besar kemungkinan mereka untuk melakukan coping diadik negatif.

Hasil di atas yang menunjukkan bahwa coping diadik negatif dipengaruhi oleh efek aktor dan efek partner mendukung pendapat Lederman, Bodenmann, Rudaz, dan Bradbury (2010 bahwa coping diadik negatif bersifat "couple oriented." Sekalipun coping diadik negatif bersifat "couple oriented" tetapi dibandingkan dengan pria, wanita lebih terpengaruh oleh stres internal suaminya. Pria memang juga terpengaruh oleh stres internal istrinya, tapi pengaruhnya tidak sebesar pengaruh stres internal suami terhadap coping negatif istri. Hal ini sesuai dengan pendapat Bodenmann, Lederman dan Bradbury (2007). Dia berpendapat dibandingkan dengan pria, wanita lebih mudah untuk menyerap stres pasangannya tapi lebih sukar untuk menularkan stres kepada pasangannya. Wanita juga lebih berorientasi interpersonal dibandingkan dengan pria, oleh karena itu wanita lebih mudah terganggu jika hubungan dengan pasangannya bermasalah (Nolen-Hoeksema and Hilt (2009). Sifat wanita yang lebih interpersonal inilah yang mungkin bisa menjelaskan hasil yang agak bertentangan antara pengaruh stres eksternal dan stres internal terhadap istri. Dibandingkan dengan pria, wanita mempunyai kemampuan pengendalian emosi pribadi lebih baik sehingga lebih mampu mencegah pengaruh stres internal supaya tidak terimbas ke stres internal, tetapi ternyata wanita lebih rentan terhadap pengaruh stres internal pasangannya. Hal ini juga mungkin terpengaruh oleh soal budaya. Wanita Indonesia dididik untuk menganggap bahwa urusan rumah tangga adalah kewajiban istri, oleh karena itu jika ada masalah dalam rumah tangga para istri lebih merasa terganggu daripada suaminya.

\section{SIMPULAN DAN SARAN}

Stres memang berpengaruh negatif terhadap kemampuan pasangan untuk mengelola stres, akan tetapi ternyata efek dari eksternal stres berbeda dengan efek dari internal stres. Stres eksternal tidak mempunyai pengaruh langsung terhadap coping diadik negatif, akan tetapi eksternal stres dapat memperbesar internal stres yang kemudian memperburuk coping diadik negatif. Memperhatikan hasil ini maka pasangan suami-istri akan mendapat manfaat jika secara pribadi mereka belajar cara mengatasi stres secara individual, sehingga mereka bisa mengelola stres eksternal dengan baik. Dengan demikian stres eksternal tidak akan merembes kedalam relasi mereka dengan pasangan. Hal ini khususnya perlu dipelajari oleh para suami karena ternyata dibandingkan dengan para istri, para suami cenderung tidak bisa mengelola stres. eksternal dengan baik.

Coping diadik negatif ternyata berorientasi pasangan, stres internal seseorang tidak hanya mempengaruhi coping diadik negatif yang bersangkutan tapi juga pasangannya. Oleh karena itu pasangan juga akan mendapat manfaat jika mereka belajar bagaimana cara mengatasi stres sebagai pasangan dengan cara yang lebih konstruktif.

Penelitian tentang pengaruh stres internal dan eksternal terhadap coping diadik negatif ini akan semakin lengkap jika peneliti juga meneliti coping pribadi, untuk melihat apakah benar pengaruh stres eksternal terhadap stres internal dimediasi/moderasi oleh coping pribadi. Hal lain yang bisa dilakukan adalah meneliti jenis stres yang lain seperti stres kronis dan stres menahun. 


\section{DAFTAR PUSTAKA}

Ackerman, R., Donnellan, M. B., \& Kashy, D. (2011). Working with dyadic data in studies of emerging adulthood: specific recommendations, general advice, and practical tips. In F. Fincham \& Ming Chui (Eds.), Romantic relationship in emerging adulthood (pp. 67-100). Cambridge, MA: Cambridge Univ Press.

Bodenmann, G. (1995). A Systemic-transactional conceptualization of stress and coping in couples. Swiss Journal of Psychology, 34-39.

Bodenmann, G. (2005). Coping dyadic and its significance for marital functioning. In T. K. Revenson, Couples coping with stress: Emerging perspectives on dyadic coping (pp. 33-50). Washington DC: APA Book.

Bodenmann, G., Lederman, T., \& Bradbury, T.N. (2007). Stress, sex, and satisfaction in marriage. Personal Relationships, 14, 551-569.

Bradbury, T. , R. Rogge \& E. Lawrence. (2001). Reconsidering the role of conflict in marriage. In Booth, Couples in conflic. London: Lawrence Erlbaum

Charania, M., \& Ickes, W. J. (2009). Research methods for the study of personal relationships. In Perlman. \&. Vangelisti, The Cambridge handbook of personal relationships (hal. 51-72). New York, NY: Cambridge University Press.

Cutrona, C.E., \& Gardner, K.A. (2006). Stress in couples: the process of dyadic coping. In Perlman \&. Vangelisti, The Cambridge handbook of personal relationship (hal. 501-515). Cambridge: Cambridge University Press

Fincham, F.D. (2003). Marital conflict: Correlates, structure and context. Current Directions in Psychological Science, 12, 23-27

Kenny, D.A., Kashy, D.A., and Cook, W.L. (2006). Dydic data analysis. New York, NY: Guilford Press.

Lazarus, R.S. \& Folkman, S. (1984). Stress, appraisal, and coping. New York, NY: Springer.

Lederman, T., Bodenmann, G., Rudaz, M., \& Bradbury, T.N. (2010). Stress, communication, and marital quality in couples. Family Relationships, 59, 195-206.

Moos, R.H. \& Holahan, C.J. (2003). Dispositional and contextual perspectives on coping: Toward and Integrative Framework. Journal of Clinical Psychology, 1387-1403.

Neff, L.A., \& Karney, B. (2004). How does context affect intimate relationships? Linking external stress and cognitive processes within marriage. Personality and Social Psychology Bulletin, 30, 134-148.

Nolen-Hoeksema, S., \& Hilt, L. M. (2009). Gender differences in depression. In I. Gotlib \& C. Hammen (Eds.), Handbook of depression (2nd ed., hal. 386-404). New York, NY: Guilford.

Randall, A.K. \& Bodenmann, G. (2009). The Role of stress on close relationships and marital satisfaction. Clinical Psychology Review, 105-115.

Rauer, A.J., Karney, B.R., Garvan, C.W. \& Hou, W. (2008). Relationship risks in context: A cumulative risk approach to understanding relationship satisfaction. Journal of Marriage and Family, 1122-1135.

Repetti, R.L. \& Wood, J. (1997). Effects of daily stress at work on mothers' interaction with preschoolers. Journal of Family Psychology, 11, 90-108. 
Rogers, S. J. and P. R. Amato. (1997). Is marital quality declining? The evidence from two generatons. Social Forces, 1089-1100.

Story, L.B., \& Bradbury, T.N. (2004). Understanding marriage and stress: Essential questions and challenges. Clinical Psychology Review, 23, 1139-1162.

\section{Internet:}

Barna, G. (2004, September 8). The Barna Update. The Barna Group: http://www.barna.org/FlexPage. aspx?Page=BarnaUpdateNarrow\&BarnaUpdateID=170 Diunduh 16 November 2007.

Putra, E.P. (24 Januari 2012). Angka perceraian pasangan Indonesia naik drastis 70 persen. Republika Online. Diunduh dari www.republika.co.id.

Whitehead, B. D. (2004). Testimony of Barbara Dafoe Whitehead, before the Committee on Health, Education, Labor and Pensions Subcommittee on Children and Families U.S. Senate.National Marriage Project: http://marriage.rutgers.edu/Publications/Print/Print $\% 20$ Whitehead $\% 20$ TESTIMONY.htm Diunduh 1 Oktober 2008 
